\title{
Niepełnosprawny jako aktywny obywatel - problematyka integracji społecznej i zawodowej osób niepełnosprawnych w Polsce
}

\section{STRESZCZENIE}

Artykuł omawia dwa podstawowe nurty aktywizacji osób niepełnosprawnych, jakimi są: (re)integracja (rehabilitacja) społeczna oraz (re)integracja (rehabilitacja) zawodowa. Przy tym aktywizacja zawodowa przedstawiona jest jako cel i rezultat przede wszystkim polityki państwa, a aktywizacja społeczna - jako przejaw i efekt funkcjonowania trzeciego sektora, współtworzonego przez organizacje pozarządowe (stowarzyszenia i fundacje). Autor wskazuje na komplementarność obu form aktywizacji, podkreślając, że obie prowadzić mają do efektu empowerment. Ponadto podkreśla brak koordynacji programów aktywizujących prowadzonych przez różne instytucje i służby: Państwowy Fundusz Rehabilitacji Osób Niepełnosprawnych, instytucje zatrudnienia socjalnego, pomoc społeczną i służby zatrudnienia.

Słowa kluczowe: osoby niepełnosprawne, polityka społeczna, integracja społeczna, integracja zawodowa, rehabilitacja społeczna, rehabilitacja zawodowa, aktywizacja, organizacje pozarządowe. 


\section{KWESTIE TERMINOLOGICZNE}

Termin „osoby niepełnosprawne” jest w języku polskim podstawowym określeniem zbiorczym dla osób nie-w-pełni-sprawnych. Termin ten przyjął się i jest używany powszechnie: w literaturze naukowej, w dokumentach urzędowych, w języku prawniczym, w mowie potocznej. Co ważne, jest określeniem chętnie stosowanym przez same osoby doświadczające niepełnosprawności. Język nauki precyzyjnie „rozpisał” niepełnosprawność - traktowaną jako „syndrom niepełnej sprawności” (Ostrowska, Sikorska, Gąciarz 2001: 151) na poszczególne wymiary, uwzględniając przy tym zarówno obiektywne deficyty i ograniczenia osób niepełnosprawnych, jak i związane z nimi czynniki społecznej marginalizacji (ibidem).

Od kilku lat podejmowane są jednak wysiłki wyparcia z dyskursu publicznego terminu "osoby niepełnosprawne" i zastąpienia go terminem „osoby z niepełnosprawnościami”. Przez zwolenników zmiany językowej ten pierwszy termin traktowany jest bowiem jako mniej "poprawny” niż drugi, a czasem wręcz jako określenie stygmatyzujące (por. Galasiński 2013).

Każda istotna zachodząca zmiana językowa jest faktem społecznym, który nie powinien uchodzić refleksji socjologicznej. Z perspektywy socjologicznej warto zadać sobie dwa pytania: (1) Jak przebiega sam proces zmiany językowej: na ile jest to proces społecznie „spontaniczny”, będący przejawem żywotności języka, a na ile proces „sterowany"?; (2) Jaką korzyść społeczną (lub stratę społeczną) taka zmiana na poziomie języka przynosi lub może przynieść? Na wstępie niniejszego opracowania przedstawię kilka uwag na ten temat, które tłumaczą, dlaczego posługiwać się będę terminem tradycyjnym.

Termin „osoby z niepełnosprawnościami” to przykład typowej kalki językowej, przenoszenia do polskiego języka - na zasadzie naśladownictwa - podobnej (choć nie 
identycznej) zmiany dokonanej już w języku angielskim. $\mathrm{W}$ anglojęzycznej literaturze przedmiotu ludzie niepełnosprawni przez długi czas określani byli jako handicapped (czyli dosłownie „upośledzeni”), który to zbiorczy termin został następnie zastąpiony określeniem disabled (dosłownie: „niesprawni”). Obecnie zaś w użyciu jest people with disabilities, które to określenie należałoby dosłownie tłumaczyć jako „ludzie z niesprawnościami”. Angielski przedrostek dis- co do zasady oznacza bowiem zaprzeczenie cechy (stanu), z którą (którym) jest kojarzony. Tak więc, o ile order oznacza porządek czy ład, to disorder - stan nieuporządkowania, nieład, bałagan. Na podobnej zasadzie ability to możność, zdolność, a disability - niemożność, niezdolność, a więc brak sprawności, czyli niesprawność. Odchodzenie $\mathrm{w}$ języku angielskim od disabled people na rzecz people with disabilities ma za zadanie nieść przekaz, że zróżnicowana w przekroju społecznym sytuacja zdrowotna, społeczna, zawodowa poszczególnych jednostek i związany z tym różny zakres ich możliwości uczestnictwa w życiu społecznym czy poruszania się na rynku pracy nie tworzy prostego dychotomicznego podziału: ludzie sprawni - ludzie niesprawni.

Innymi słowy, chodzi o przekaz, że określone ograniczenia, jak wada wzroku, ograniczenia ruchowe, choroba przewlekła itp. działają niejako „punktowo”, „obszarowo” i nie odbierają człowiekowi od razu „całej sprawności”, nie czynią go z miejsca jednostką niesprawną. Ale język polski potrafi niezwykle celnie oddać taki właśnie stan rzeczy określeniem „niepełnosprawność”, podczas gdy język angielski takim terminem nie dysponuje. Dlatego, o ile zrozumiała jest zmiana dokonującą się w języku angielskim, o tyle nie ma merytorycznej potrzeby sztucznego tworzenia $\mathrm{w}$ języku polskim nowego terminu - „osoba z niepełnosprawnością”, wątpliwą wartość dodaną miałoby też określenie „osoba z niesprawnością," zwłaszcza jako określenie podstawowe.

Promowana obecnie kalka językowa ma dwa istotne ograniczenia. Po pierwsze, może być adekwatnie (choć 
również nie do końca poprawnie) stosowana jedynie w liczbie mnogiej - „osoby z niepełnosprawnościami” - na określenie ogółu ludzi mających różne ograniczenia, czyli niesprawności czy „niepełnosprawności”. Ale już w przypadku konkretnego człowieka nie wiadomo, czy posługiwać się określeniem „osoba z niepełnosprawnością” czy „osoba z niepełnosprawnościami”, bo to zależy od kontekstu, czy dana osoba ma jedną określoną dysfunkcję organizmu (np. wadę wzroku) czy też ma np. dysfunkcje sprzężone - chorobę przewlekłą powiązaną z niepełnosprawnością intelektualną czy ograniczenie słuchu sprzężone $\mathrm{z}$ istotną wadą wymowy itd. Język angielski, warto o tym pamiętać, ma przy tym skłonność do traktowania jako policzalne stanów, zjawisk itp., które z kolei w języku polskim funkcjonują jako niepoliczalne. Takimi właśnie określeniami są „niepełnosprawność” czy „dobroczynność”.

Dobroczynność w języku polskim jest bowiem pewną ogólną postawą lub zjawiskiem społecznym, nie zaś zbiorem czynności: poszczególne czyny dobroczynne nie są więc „dobroczynnościami”, choć składają się na nie określone czynności. Natomiast w języku angielskim charity to dobroczynność, ale także nazwa organizacji dobroczynnych, podmiotów jak najbardziej policzalnych (funkcjonuje oficjalny rejestr charities); stąd liczba mnoga w użyciu jest oczywista. Analogicznie rzecz się ma z uczciwością, prawdomównością czy niezgrabnością. Przykłady można by mnożyć. Wszystkie one wskazują, że dokonujące się na naszych oczach „upoliczalnienie” niepełnosprawności jest przykładem swoistej kolonizacji języka polskiego przez wpływy anglosaskie.

Po drugie, termin „osoba $\mathrm{z}$ niepełnosprawnością” nie zawsze jest określeniem trafnym nawet w sytuacji, gdy wskazywać ma na jedną określoną dysfunkcję konkretnej osoby. Jeśli na przykład owa niepełnosprawność polega na niedowidzeniu - termin jest trafny. Ale jeśli osoba ta nie widzi w ogóle, to jej narząd wzroku jest całkowicie niesprawny, a nie nie-w-pełni-sprawny. Język polski precyzyjnie rozróż- 
nia między osobą niedowidzącą i osobą niewidomą - każda $\mathrm{z}$ nich jest niepełnosprawna, ale tylko jedna $\mathrm{z}$ nich to osoba z niepełnosprawnym narządem wzroku; druga ma zaś ten narząd całkowicie niesprawny. Ta druga co najwyżej jest osobą „z niesprawnością” (narządu wzroku); i tak ujmuje to termin anglojęzyczny person with disability. W języku polskim najlepiej określić taką osobę jako osobę niewidomą lub powiedzieć, że jest osobą niepełnosprawną.

Szukając najbardziej trafnych terminów, nie warto kierować się naśladownictwem ani polityczną poprawnością ${ }^{1}$, ale merytorycznym namysłem, przy zachowaniu społecznej wrażliwości (empatii). Adekwatny termin to taki, który zarazem:

(1) najlepiej opisuje rzeczywistość; jest trafny, gdyż precyzyjnie zakreśla zbiór desygnatów danego pojęcia w różnych kontekstach - ten warunek spełnia termin „osoba niepełnosprawna”;

(2) jest zgodny z podstawowymi regułami językowymi; język polski, zaznaczmy raz jeszcze, nie zna liczby mnogiej rzeczownika „niepełnosprawność, dlatego jej stosowanie jest zabiegiem sztucznym, wbrew ogólnej zasadzie językowej;

(3) ma możliwie wysoki „współczynnik humanistyczny”, co jest istotne zwłaszcza w przypadku określeń dotyczących ludzi; termin „osoba niepełnosprawna” bez wątpienia jest takim właśnie terminem.

Co więcej, „osoba niepełnosprawna” - warto to podkreślić - to termin o najwyższym „współczynniku humanistycznym" spośród wszystkich dostępnych w języku polskim bliskoznacznych terminów, ze względu nie tylko ma precyzyjność i prawidłowy społeczny kontekst „niepełnosprawności”

1 Więcej o przejawach politycznej poprawności w reformowaniu języka polityki społecznej i pracy socjalnej: por. opracowanie poświęcone zmianom językowym w amerykańskiej Encyklopedii pracy socjalnejRymsza 2002. 
jako niepełnej sprawności, a nie niesprawności, ale także upodmiotowiającą moc rzeczownika „osoba”. Dlatego właśnie, w moim przekonaniu, warto trzymać się terminu „osoba niepełnosprawna” / „osoby niepełnosprawne” i odchodzić od tego określenia tylko wówczas, gdy mowa o konkretnych niesprawnościach, czyli w sytuacjach, gdy niejako „rozagregatowujemy” wspomniany syndrom niepełnej sprawności na zestaw określonych niesprawności i analizujemy sytuację określonych grup „kategorialnych” - a więc ludzi z określonymi ograniczeniami czy dysfunkcjami konkretnych narządów (osoby z wadą wzroku, osoby o ograniczonej mobilności ruchowej, osoby z zaburzeniami psychicznymi itd.).

\section{WSPARCIE AKTYWIZUJĄCE DLA OSÓB NIEPEŁNOSPRAWNYCH JAKO PRIORYTET WSPÓŁCZESNEJ POLITYKI SPOŁECZNEJ}

Działania ukierunkowane na wparcie i aktywizację osób niepełnosprawnych to jeden $\mathrm{z}$ dynamiczniej rozwijających się w XXI w. działów polityki społecznej. Owa dynamika wymaga podkreślenia, gdyż doświadczamy w Europie (i nie tylko w Europie) dłuższego, zapoczątkowanego jeszcze w latach 80. XX w., okresu „dekoniunktury” na wydatki socjalne, związanego najpierw z narastającym kryzysem ekonomicznym poszczególnych państw dobrobytu, a następnie z makrokryzysem globalizujących się rynków finansowych. Niemniej jednak, chociaż w wielu dziedzinach polityki społecznej nastał czas cięć socjalnych, nakłady na programy wsparcia - zwłaszcza tego o charakterze aktywizującym adresowane do osób niepełnosprawnych rosną, a nie maleją. Coraz bardziej popularny staje się ponadto społeczny model rozwiązywania problemu niepełnosprawności (por. Gąciarz 2014); model znacznie bardziej holistyczny, ale i znacznie bardziej kosztowny niż dominujący wcześniej model rehabilitacyjny. Jakie są uwarunkowania nowego po- 
dejścia do niepełnosprawności jako problemu społecznego? W jednym z wcześniejszych opracowań (por. Rymsza 2011: 180-182) wskazałem na trzy istotne uwarunkowania:

1) Coraz mocniejsza jest legitymizacja dla działań publicznych na skutek rosnącej skali problemu - w starzejących się społeczeństwach dobrobytu systematycznie rośnie liczba osób niepełnosprawnych, gdyż starość jest silnie sprzężona z niedołężnością i niepełnosprawnością;

2) Praktycznie osiągnięty został konsens społeczny i polityczny wokół idei wyrównywania szans życiowych osób niepełnosprawnych $\mathrm{w}$ ramach realizowanych polityk publicznych; wyrazem tego jest ONZ-owska Karta Praw Osób Niepełnosprawnych;

3) Coraz silniejszy priorytet $w$ polityce społecznej mają programy aktywizacji życiowej, inkluzji społecznej i reintegracji zawodowej różnych grup podlegających społecznej marginalizacji i wykluczeniu ze względu na posiadane / doświadczane deficyty i ograniczenia; jedną z takich grup „kategorialnych” współtworzą osoby niepełnosprawne.

Dodajmy przy tym, że postęp medycyny i rozwój nowych form i technik rehabilitacji - z jednej strony, oraz zmiany w organizacji życia zbiorowego i funkcjonowaniu rynków pracy - z drugiej, sprawiają, że możliwość uczestnictwa w życiu społecznym, w tym prowadzenia aktywności ekonomicznej, mogą uzyskać osoby niepełnosprawne tradycyjnie uznawane za jednostki w sposób trwały społecznie wycofane, funkcjonujące wyłącznie w sferze życia prywatnego, praktycznie poza sferą publiczną oraz całkowicie niezdolne do pracy.

Wspomniany już społeczny model rozwiązywania problemu niepełnosprawności zakłada ponadto, że to nie tylko osoby niepełnosprawne poprzez programy rehabilitacji, reintegracji czy aktywizacji mają przystosowywać się do reguł i instytucjonalnych ram społecznego funkcjonowania, 
ale również szeroko rozumiane otoczenie społeczne ma za zadanie dostosowywać się do możliwości osób niepełnosprawnych. Niepełnosprawność staje się właściwie stanem „normalnym”, a nie nietypowym, na tej zasadzie, że każdy człowiek ma jakieś ograniczenia, deficyty i powinien mieć szansę na możliwie pełne uczestnictwo w życiu społecznym pomimo nich. System społeczny ma być bowiem systemem o możliwie wysokim współczynniku inkluzyjności.

Znaczna część współczesnej literatury przedmiotu dotyczącej zagadnień rehabilitacji, inkluzji i integracji osób niepełnosprawnych koncentruje się na zagadnieniach związanych z możliwościami podnoszenia zdolności zatrudnieniowej (ang. employability) tych osób, a zwłaszcza promowaniu ich zatrudnienia na otwartym rynku pracy². Należy jednak podkreślić, że integracja osób niepełnosprawnych z rynkiem pracy nie jest celem samym w sobie, a jedynie drogą do ich życiowego usamodzielnienia i powinna być traktowana jako element procesu inkluzji społecznej. W niniejszym opracowaniu podjęta jest próba uwzględnienia obu nurtów aktywizacji osób niepełnosprawnych, przy czym aktywizacja zawodowa przedstawiona jest w większym stopniu jako cel i rezultat polityki państwa, a aktywizacja społeczna jako przejaw i efekt funkcjonowania trzeciego sektora - sformalizowanego segmentu społeczeństwa obywatelskiego, współtworzonego przez organizacje pozarządowe (stowarzyszenia i fundacje).

Należy przy tym mieć na uwadze, że nurt aktywizacji (reintegracji społecznej i zawodowej) nie wyczerpuje zakresu wsparcia, którego potrzebują osoby niepełnosprawne. Istotnym są również usługi opiekuńcze świadczone tym, których niepełnosprawność nie poddaje się działaniom rehabilitacyjnym, a ograniczone rezultaty przynoszą też działania kom-

2 Por. np. Giermanowska 2007 oraz Ciura 2007 i przywoływane tam pozycje źródłowe. Więcej o employability - por. Karwacki, Kaźmierczak, Rymsza 2014, rozdz. 6 (autorstwa T. Kaźmierczaka). 
pensacyjne. Dotyczy to zwłaszcza niepełnosprawnych seniorów, w przypadku których niepełnosprawność jest silnie skorelowana $\mathrm{z}$ postępującą $\mathrm{z}$ racji wieku ogólną niedołężnością. Nurt aktywizacji zawodowej jest w pewien sposób „nieczuły” na tę kwestię, przejawiając tendencję do ograniczania wsparcia wyłącznie do osób „rokujących” na rynku pracy. Nurt aktywizacji społecznej dostrzega tę kwestię i związaną $\mathrm{z}$ nią pewną ambiwalencję. Z jednej strony działania opiekuńcze o charakterze wyręczającym mogą nieść ze sobą efekt dezaktywizacji życiowej, niekorzystny tak dla stanu zdrowia osób niepełnosprawnych, jak i ich społecznego funkcjonowania. $\mathrm{Z}$ drugiej strony, usługi opiekuńcze, ograniczając deprywację potrzeb, mogą podtrzymać społeczne wymiary funkcjonowania osób niepełnosprawnych, stanowiąc dopełnienie lub jedyny możliwy substytut wsparcia aktywizującego.

\section{REHABILITACJA ZAWODOWA I SPOŁECZNA OSÓB NIEPEŁNOSPRAWNYCH W POLSCE PO 1989 R. - ROZWIAZZANIA PRAWNO-INSTYTUCJONALNE I POLITYKA PAŃSTWA}

W polityce społecznej wobec osób niepełnosprawnych prowadzonej w Polsce po 1989 r. wyróżnić można cztery zasadnicze okresy ${ }^{3}$. Periodyzacja ta znajduje odzwierciedlenie: (i) w działaniach ustawodawcy, których rytm wyznaczają kolejne kadencje parlamentarne, (ii) w stosowanych na ich podstawie przez administrację publiczną rozwiązaniach

3 Meandry polityki społecznej w Polsce po 1989 r. analizowałem w konwencji trzech fal reform społecznych, eksponując kluczowe znaczenie okresów kulminacji prac reformatorskich (por. np. Rymsza 2013: 205-258). Sektorowa polityka wobec problemu niepełnosprawności nie do końca wpisuje się w ramy interpretacyjne takiej analizy i „porządkowanie wydarzeń" warto tu przeprowadzić nieco inaczej, zwracając uwagę na efekty nakładających się zmian w dłuższych przedziałach czasowych niż na konsekwencje określonych decyzji i programów politycznych („reform”). 
instytucjonalnych oraz (iii) w podejmowanej oddolnie, ale z uwzględnieniem tworzonych odgórnie ram formalno-prawnych, aktywności podmiotów trzeciego sektora.

\section{Pierwszy okres: lata 1989-1993}

Lata 1989-1993 to okres prac nad stworzeniem i wdrożeniem koncepcji rehabilitacji osób niepełnosprawnych jako wsparcia aktywizującego, ukierunkowanego na integrację z rynkiem pracy (rehabilitacja zawodowa). Za cezurę czasową tego okresu można przyjąć rozwiązanie Sejmu I kadencji przez prezydenta Lecha Wałęsę (1993). Wygranie wyborów i zawiązanie koalicji przez partie postkomunistyczne doprowadziło bowiem do wyhamowania reform systemowych podjętych przez obóz solidarnościowy. W pierwszych latach transformacji ustrojowej w polityce społecznej dominowały działania osłonowe, będące „wentylem bezpieczeństwa” dla reform gospodarczych (Rymsza 2013). Jednak w odniesieniu do problemu niepełnosprawności podjęto próbę zbudowania systemu wsparcia o charakterze aktywizującym, przy wykorzystaniu odziedziczonej po PRL infrastruktury spółdzielczości inwalidzkiej ${ }^{4}$. Najważniejszym przejawem ówczesnego podejścia była uchwalona w 1991 r. ustawa

4 Spółdzielczość inwalidzka była „produktem” socjalistycznej polityki produktywizacji (por. Kaźmierczak 2003), w myśl której niepełnosprawni obywatele, na ile to możliwe, powinni byli być produktywni tak jak obywatele pełnosprawni. Paradoksalnie, polityka produktywizacji upowszechniała $\mathrm{w}$ dużej mierze zatrudnienie nieproduktywne, a "produktywizacja niepełnosprawnych” powielała wszystkie „przerostowe” błędy polityki pełnego zatrudnienia. Ale miała też dodatkowe skutki uboczne: dla niepełnosprawnych stworzono odrębny sektor spółdzielczości inwalidzkiej, tworzący substandardowe miejsca pracy. W warunkach gospodarki niedoboru spółdzielnie inwalidzkie utrzymywały się na rynku, ale po wprowadzeniu mechanizmów konkurencji groziła im upadłość. Wdrożona u progu lat 90 . XX w. polityka aktywizacji niepełnosprawnych sprawiła, że spółdzielnie te miały możność przekształcenia się w zakłady pracy chronionej i nie podzieliły losu innego „produktu” gospodarki socjalistycznej - Państwowych Gospodarstw Rolnych, które uległy likwidacji. 
o zatrudnieniu i rehabilitacji zawodowej osób niepełnosprawnych ${ }^{5}$. Cele ustawodawcy były następujące:

(1) upowszechnianie zatrudniania osób niepełnosprawnych na otwartym rynku pracy;

(2) wsparcie finansowe pracodawców tworzących miejsca pracy na rynku chronionym, czyli w zakładach pracy chronionej;

(3) „,usektorowienie” (instytucjonalizacja) polityki wobec osób niepełnosprawnych przez powołanie funduszu celowego - Państwowego Funduszu Rehabilitacji Osób Niepełnosprawnych (PFRON), nadzorowanego przez Pełnomocnika Rządu do spraw Osób Niepełnosprawnych.

Pierwszy cel miał charakter główny, a cele drugi i trzeci były celami uzupełniającymi. Źródłem finansowania nowej sektorowej polityki stała się danina publiczna (podatek celowy) nałożona na pracodawców niezatrudniających niepełnosprawnych $\mathrm{w}$ odpowiednim limicie kwotowym ${ }^{6}$ i odprowadzana do PFRON. Jak się okazało, pracodawcy generalnie woleli płacić daninę na Fundusz niż zatrudniać osoby niepełnosprawne, co sprawiło, że Fundusz dysponował sporymi zasobami pieniężnymi.

Pierwsze lata transformacji były jednocześnie okresem tworzenia przez państwo przestrzeni dla aktywności społecznej i obywatelskiej, a kluczowe znaczenie miało tu uchwalenie w kwietniu 1989 r. w wyniku porozumień Okrągłego Stołu ustawy - Prawo o stowarzyszeniach ${ }^{7}$. Środowisko osób niepełnosprawnych okazało się jednym z tych, w którym podjęto działania pomocowe i samopomocowe $\mathrm{w}$ ramach organizacji pozarządowych. Tak więc, podczas gdy „sektorowa” polityka państwa promowała rehabilitację zawodową

5 Dz.U. z $1991 \mathrm{Nr}$ 46, poz. 201.

6 Rozwiązanie kwotowe przyjęte jest w sporej części państw europejskich. Bliższe informacje o rozwiązaniu polskim - por. Golinowska 2004.

7 Dz.U. z 1989 Nr 20, poz. 104. 
osób niepełnosprawnych, w odradzającym się społeczeństwie obywatelskim zawiązywały się struktury wspierające i kanalizujące aktywność społeczną osób niepełnosprawnych i na rzecz osób niepełnosprawnych.

\section{Drugi okres: lata 1993-2001}

Okres drugi (lata 1993-2001) obejmuje dwie kadencje parlamentarne i rządy dwóch koalicji: najpierw Sojusz Lewicy Demokratycznej - Polskie Stronnictwo Ludowe, a następnie Akcja Wyborcza Solidarność - Unia Wolności. Były to kadencje zasadniczo odmienne: pierwszy rząd unikał reform systemowych (koncepcja „administrować, nie rządzić”), a drugi wdrożenie pakietu reform społecznych przyjął za oś swego programu politycznego (Kolarska-Bobińska, red. 2000). Jednak w odniesieniu do problemu niepełnosprawności obserwowaliśmy ciągłość działań aparatu państwa i służb społecznych. Następowała instytucjonalizacja uchwalonych w poprzednim okresie rozwiązań formalno-prawnych wyznaczających ramy i logikę funkcjonowania systemu PFRON, przy czym w praktyce stopniowo odchodzono od priorytetu zawartego w koncepcji z 1991 r., a dotyczącego promocji zatrudnienia osób niepełnosprawnych na otwartym rynku pracy. Po pierwsze, stawało się coraz bardziej jasne, że finansowym beneficjentem systemu PFRON są raczej zakłady pracy chronionej (pobierające dotacje) niż przedsiębiorcy $\mathrm{z}$ otwartego rynku pracy (płacący daniny na PFRON $)^{8}$. Po drugie, coraz więcej środków Funduszu przeznaczano na działania z zakresu szeroko rozumianej rehabilitacji społecznej kosztem działań stricte prozatrudnieniowych. Przykładowo, warsztaty terapii zajęciowej, mające formalnie za zadanie prowadzenie terapii przez pracę w celu przywrócenia zdolności zatrudnieniowej osób niepełnosprawnych z orzeczoną trwałą niezdolnością

8 Stan ten spotykał się z krytyką środowisk eksperckich - por. np. Golinowska 2007: 93. 
do pracy, w praktyce pełniły funkcje instytucji reintegracji społecznej, wypełniając w ten sposób lukę w infrastrukturze wsparcia środowiskowego osób niepełnosprawnych.

Potwierdzeniem trwałości wspomnianych tendencji w zarządzaniu systemem PFRON i alokowaniem jego zasobów było uchwalenie w $1997 \mathrm{r}$. nowej ustawy o rehabilitacji zawodowej i społecznej oraz zatrudnianiu osób niepełnosprawnych'. Symptomatyczne dla kierunku ewolucji było już samo umieszczenie zatrudnienia na końcu trójczłonowego tytułu tego aktu prawnego. Nowa ustawa nie stanowiła jednak przełomu, gdyż w dużej mierze miała ona charakter porządkujący: przeniesiono do niej liczne regulacje zawarte we wcześniejszej, wielokrotnie nowelizowanej, a przez to mało czytelnej ustawie.

Podstawowych założeń polityki państwa wobec problemu niepełnosprawności nie zmieniły również czteroletnie rządy koalicji AWS-UW (1997-2001). Wdrożone przez rząd premiera Jerzego Buzka w latach 1999-2000 cztery reformy społeczne nie wniosły bowiem nowej jakości do tej polityki. Nastąpiła reorganizacja publicznych służb zatrudnienia, które z wydzielonej administracji rządowej stały się częścią zespolonej administracji powiatu. Ponadto powołanym powiatowym centrom pomocy rodzinie powierzono zadanie wspierania osób niepełnosprawnych. Znaczenie obu tych zmian organizacyjnych było jednak drugorzędne, gdyż rola publicznych służb zatrudnienia $\mathrm{w}$ promowaniu aktywności zawodowej osób niepełnosprawnych była (i nadal jest) znikoma, a powiatowe centra nie stały się kreatorami czy koordynatorami lokalnej polityki społecznej wobec niepełnosprawności; po prostu administrują przyznanymi im przez PFRON środkami na tzw. programy celowe. Zadania te w podobny sposób i z podobnym skutkiem mogłyby wypełniać inne podmioty.

9 Dz.U. 1997 Nr 139, poz. 776. 
Systematycznie rosło natomiast znaczenie organizacji pozarządowych. Logika funkcjonowania systemu PFRON sprawiała, że wiele z nich decydowało się być organami prowadzącymi warsztaty terapii zajęciowej, uczestniczyły też w organizacji turnusów rehabilitacyjnych i innych przedsięwzięć finansowanych ze środków Funduszu. Cały czas brakowało jednak podstaw prawnych systematycznej współpracy międzysektorowej.

\section{Trzeci okres: lata 2001-2007}

Okres trzeci, zapoczątkowany w 2001 r. i trwający do 2007 r., również objął dwie kolejne kadencje parlamentarne, z których druga została skrócona w wyniku samorozwiązania się Sejmu. Okres ten charakteryzował się większym wyczuleniem ustawodawcy i administracji na problem wykluczenia społecznego oraz rosnącym poparciem dla działań aktywizujących. W ramach systemu PFRON wprowadzono możliwość prowadzenia rehabilitacji osób niepełnosprawnych w zakładach aktywności zawodowej - podmiotach usytuowanych „w połowie drogi” między warsztatami terapii zajęciowej i zakładami pracy chronionej. Przede wszystkim jednak niezależnie od tego systemu stworzono infrastrukturę zatrudnienia socjalnego, w ramach której funkcjonują przedzatrudnieniowe centra integracji społecznej i kluby integracji społecznej oraz przedsiębiorstwa inkluzji społecznej przez pracę (ang. work integration social enterprises - WISE). Te ostatnie prowadzone są głównie w formie spółdzielni socjalnych, ale także jako działalność gospodarcza organizacji pozarządowych (szczegółowa charakterystyka systemu zatrudnienia socjalnego - por. Piątek 2012: 229-293).

O ile scharakteryzowany wcześniej system rehabilitacji osób niepełnosprawnych stworzony został „pod zagospodarowanie" środków funduszu celowego - PFRON, to system zatrudnienia socjalnego zbudowano jako instytucjonalny mechanizm absorpcji funduszy unijnych. Można powiedzieć, że zwrot w kierunku aktywnej polityki społecznej był 
konsekwencją akcesji Polski do Unii Europejskiej i starań ówczesnego rządu SLD-PSL (2001-2005) do uwzględnienia priorytetów unijnej polityki przeciwdziałania wykluczeniu społecznemu. Zwrot ten można jednak także interpretować jako wyraz uwzględnienia własnych doświadczeń transformacyjnych Polski (por. Rymsza 2012a).

Rzecz w tym, że system zatrudnienia socjalnego de facto dubluje rozwiązania instytucjonalne stworzone dekadę wcześniej w celu aktywizacji zawodowej osób niepełnosprawnych, tyle że adresuje wsparcie do szerszej kategorii osób wykluczonych społecznie. Podstawą funkcjonowania tego systemu są rozwiązania formalno-prawne zawarte w ustawach: o zatrudnieniu socjalnym z 2003 r. ${ }^{10}$ i o spółdzielniach socjalnych z $2006 \mathrm{r}^{11}$, a w pewnym zakresie także w ustawie o promocji zatrudnienia i instytucjach rynku pracy z $2004 \mathrm{r}^{12}$

Ze względu na brak koordynacji działań aktywna polityka społeczna nie jest polityką wielosektorową (por. ujęcie wielosektorowości polityki społecznej w: Grewiński 2009), ale raczej zbiorem funkcjonujących równolegle polityk sektorowych. Dość powiedzieć, że od 2003 r. osoby niepełnosprawne mogą $\mathrm{w}$ Polsce korzystać $\mathrm{z}$ aż czterech ścieżek wsparcia aktywizującego: (i) ścieżki usamodzielniania życiowego w ramach pomocy społecznej, (ii) ścieżki prozatrudnieniowej prowadzonej przez publiczne służby zatrudnienia, (iii) ścieżki rehabilitacyjnej w ramach systemu PFRON oraz (iv) ścieżki reintegracyjnej w ramach systemu zatrudnienia socjalnego (por. zestawienie tabelaryczne w: Rymsza 2012b: 37). Postulat „integracji reintegracji” (Rymsza 2013: 348-355) rysuje się tu aż nazbyt widocznie.

Trzeci wyróżniony okres to ponadto czas krystalizowania się modelu współpracy międzysektorowej na linii

10 Dz.U. 2003 Nr 122, poz. 1143.

11 Dz.U. 2006 Nr 94, poz. 651.

12 Dz.U. 2004 Nr 99, poz. 1001. 
administracja publiczna - trzeci sektor. Kluczowe dla kształtu tego modelu są regulacje prawne zawarte w ustawie o działalności pożytku publicznego i o wolontariacie z 2003 r. ${ }^{13}$ Model ten koncentruje się na odpłatnym zlecaniu zadań publicznych organizacjom pozarządowym i podmiotom $\mathrm{z}$ nimi zrównanym ${ }^{14}$ przy wykorzystaniu dwóch trybów finansowych (powierzenia i wspierania) oraz procedury konkursów ofert ${ }^{15}$. Można powiedzieć, że organizacje pozarządowe okazały się zbiorowym nośnikiem rozwiązań innowacyjnych i indywidualizacji wsparcia aktywizującego udzielanego osobom niepełnosprawnym.

Lata 2005-2007, stosunkowo krótki okres rządów najpierw koalicji Prawo i Sprawiedliwość - Liga Polskich Rodzin - Samoobrona, a następnie mniejszościowego gabinetu PiS, nie wniosły nowej jakości w zakresie polityki rozwiązywania problemu niepełnosprawności. Obszar tej polityki sektorowej, podobnie jak całej polityki społecznej, pomimo hasła budowy „Polski solidarnej” nie okazał się bowiem obszarem priorytetowym $\mathrm{w}$ ramach programu budowy IV Rzeczpospolitej.

\section{Czwarty okres: lata 2007-2015}

Po 2007 r. w okresie dwukadencyjnych rządów Platformy Obywatelskiej w koalicji z Polskim Stronnictwem Ludowym nie wprowadzono żadnych istotnych zmian strukturalnych w zakresie rehabilitacji / reintegracji / usamodzielniania / zatrudniania osób niepełnosprawnych. Kontynuowano zapoczątkowane wcześniej działania w poszczególnych „segmentach" programów publicznych, nie podejmując prób ich

13 Dz.U. 2003 Nr 96, poz. 873.

14 Chodzi przede wszystkim o kościelne podmioty trzeciego sektora, a także o spółdzielnie socjalne, które ustawodawca na mocy przepisów przywołanej ustawy zrównał w uprawnieniach z zakresu prowadzenia działalności pożytku publicznego z organizacjami pozarządowymi. Por. Kamiński 2012.

15 Przetargi publiczne też są dopuszczane. 
integracji czy choćby koordynacji. Zdecentralizowano natomiast system absorpcji środków unijnych, dowartościowując rolę województw względem poziomu centralnego. Reorganizacja ta była niezbędna ze względu na znacznie większą skalę absorpcji przez Polskę funduszy unijnych w okresie programowania 2007-2013 niż miało to miejsce w okresie 2004-2006, czyli bezpośrednio po akcesji naszego kraju do Unii Europejskiej. Doprowadziła ona jednak do dalszej dekompozycji systemu wsparcia aktywizującego, gdyż efekt usektorowienia został dodatkowo sprzężony z efektem regionalizacji.

Skuteczne prowadzenie określonych policies poprzez unijne programy operacyjne $\mathrm{w}$ warunkach kultury przetargowo-projektowej wymagają wysokich kompetencji w zakresie zarządzania, w tym umiejętnej implementacji reguł tak new public management (nowe zarządzanie publiczne), jak i new mode of governance (tryb współrządzenia) ${ }^{16}$. Kompetencje te zarówno w środowiskach decydenckich, jak i wśród kadr zarządzających średniego stopnia okazały się niskie. W rezultacie polityka państwa w tym obszarze w dużej mierze jest polityką absorpcji funduszy i polega na koncentrowaniu się na sprawnym wydatkowaniu środków finansowych przy spełnieniu unijnych wymogów formalnych i przy marginalizacji znaczenia celów merytorycznych samych polityk publicznych.

Po 2007 r. ujawnił się też nowy typ zachowań zbiorowych wśród kluczowych aktorów systemu PFRON - pracodawców. Błędnym założeniem reformy z 1991 r. było, przypomnijmy, przyjęcie za pewnik, że polscy pracodawcy w okresie recesji gospodarczej początku lat 90 . XX w. będą unikali dodatkowego obciążenia finansowego, co miało wywołać efekt upowszechnienia zatrudniania osób niepełnosprawnych na otwartym rynku pracy. Jak się okazało, pracodawcy

16 Zestawienie i porównanie reguł zarządzania w obu trybach - Frączkiewicz-Wronka 2014: 21-93. 
woleli wówczas płacić daninę na $\mathrm{PFRON}^{17}$. W okresie pierwszej fazy globalnego kryzysu finansowego (2008-2010) sytuacja odwróciła się. Pracodawcy z otwartego rynku pracy w sytuacji światowej dekoniunktury gospodarczej zaczęli zatrudniać niepełnosprawnych, przez co przychody Funduszu mocno się skurczyły. To z kolei sprawiło, że zmniejszyły się dotacje z Funduszu nie tyle na zatrudnienie osób niepełnosprawnych na chronionym rynku pracy (tu poziom dotacji zapewnia odpowiedni algorytm zapisany w ministerialnym rozporządzeniu), ale uznaniowe dotacje na działania rehabilitacyjne i reintegracyjne prowadzone przez organizacje pozarządowe. Ucierpiała więc przede wszystkim sfera rehabilitacji społecznej osób niepełnosprawnych.

Efekt „krótkiej kołdry” wywołał debatę o skuteczności różnych form wspierania osób niepełnosprawnych jako argumentu racjonalizującego alokację środków publicznych i obnażył podstawową wadę PFRON-owskiego systemu rehabilitacji. Jest nią niska skuteczność zatrudnieniowa, pomimo wprowadzenia rozbudowanych rozwiązań prawno-instytucjonalnych i zapewnienia relatywnie stabilnych źródeł finansowania publicznego (por. Rymsza, Giermanowska 2009). Problem ten $\mathrm{w}$ środowisku eksperckim rozpoznany został wcześniej, ale uchodził uwagi w dyskursie publicznym. Od 2007 r. świadomość tego problemu narasta; władza publiczna nie podjęła jednak żadnej próby skutecznego podniesienia efektywności systemu. Raz po raz powraca więc postulat radykalny: likwidacji systemu PFRON, który tylko wzmacnia mechanizmy obronne w zakonserwowaniu status quo.

17 Należy zaznaczyć, że przykład w pewnym stopniu „szedł z góry”: $\mathrm{z}$ zupełnie niezrozumiałych powodów z obowiązku zatrudniania niepełnosprawnych została zwolniona, wkrótce po uchwaleniu ustawy, administracja publiczna (sic!). Pomijając edukacyjną funkcję wzorów zarządzania w instytucjach publicznych (reformy systemowe należy zaczynać „od siebie"), w instytucjach tych znacznie łatwiej zatrudniać osoby niepełnosprawne - są one bowiem nastawione na spełnianie określonych standardów działania, a nie na maksymalizację zysku; wydajność ekonomiczna nie jest więc kluczowym czynnikiem oceny pracy. 
W latach 2007-2015 umacniał się model współpracy międzysektorowej w zakresie realizacji zadań publicznych, w tym pomocy osobom niepełnosprawnym, czemu towarzyszyło zjawisko stopniowej governmentalizacji sektora pozarządowego $^{18}$. Niedorozwój kultury partnerstwa i współpracy w duchu governance wynikał zarówno $\mathrm{z}$ nierówności potencjału podejmujących współpracę stron (dominująca pozycja sektora publicznego; niski potencjał ekonomiczny sektora pozarządowego), jak i wykorzystywania tej przewagi przez świat urzędniczy dla forsowania zasad współpracy charakterystycznych dla kultury organizacyjnej instytucji publicznych. To z kolei prowadziło do biurokratyzacji organizacji pozarządowych i ograniczenia ich niezależności. Skutkiem ubocznym tego procesu jest też zjawisko polaryzacji wewnątrz sektora pozarządowego, polegającej na narastaniu różnic między organizacjami wchodzącymi w system współpracy międzysektorowej i niewchodzącymi oraz wzajemnej obcości i dystansu sektora "trzeciego” (sformalizowanego) i sektora „czwartego” (inicjatyw niesformalizowanych). Polaryzacja ta jest dobrze widoczna także w środowisku organizacji prowadzących działalność na rzecz osób niepełnosprawnych.

\section{REHABILITACJA, INTEGRACJA I AKTYWIZACJA OSÓB NIEPEŁNOSPRAWNYCH W POLSCE - DZIAŁANIA TRZECIEGO SEKTORA I SAMOORGANIZACJA ŚRODOWISKOWA}

Trzeci sektor tworzą organizacje pozarządowe, określane też jako organizacje społeczne, organizacje non-profit, organizacje obywatelskie, organizacje ochotnicze. W literaturze przedmiotu od wielu lat trwa nieprzerwana dyskusja

18 Pogłębiona charakterystyka procesu governmentalizacji sektora pozarządowego w: A. Rymsza 2013. 
na temat adekwatności tych terminów. Przywiązanie do konkretnych terminów wydaje się być przejawem odmiennej wrażliwości różnych badaczy i ujawnianych różnic poglądów co do wagi poszczególnych konstytutywnych cech tychże organizacji - każda z nazw eksponuje bowiem inną cechę ${ }^{19}$. W dalszej narracji używany jest termin „organizacje pozarządowe” (non-governmental organizations - NGOs) nie dlatego, że jest to określenie najtrafniejsze, ale jako termin funkcjonujący w obrocie prawnym, gdyż posługuje się nim polski ustawodawca ${ }^{20}$. Warto jednak w tym miejscu przywołać ogólnie przyjętą w literaturze przedmiotu definicję organizacji wypracowaną na podstawie syntezy porównawczych badań empirycznych przez zespół Lestera Salamona (por. Salamon 2001: 163-164). Definicja ta uwzględnia sześć cech konstytutywnych (a więc jednakowo ważnych) organizacji pozarządowych (Salamon posługuje się terminem nonprofit organizations):

(1)private - prywatny charakter (czyli oddzielenie od państwa, takie rozumienie nie zaprzecza społecznemu charakterowi organizacji),

(2) self-governed - samorządność (czyli zdolność organizacji do podejmowania decyzji we własnych sprawach),

(3) non-profit distributing - niekomercyjny charakter (czyli zakaz dystrybucji nadwyżki finansowej między członków, założycieli, udziałowców),

(4) on public benefit - działanie na rzecz pożytku publicznego (tworzenie korzyści społecznej, społecznej wartości dodanej),

(5) voluntary - dobrowolne uczestnictwo (zarówno w przypadku członków, personelu płatnego, jak i wo-

19 Więcej o definicyjnych aspektach - por. np. Chimiak 2006: 61-88.

20 Definicja legalna organizacji pozarządowej znajduje się w ustawie o działalności pożytku publicznego i o wolontariacie z 2003 r., Dz.U. 2003 Nr 96, poz. 873. 
lontariuszy, przy czym obecność tych ostatnich w organizacji jest szczególnie wskazana) ${ }^{21}$.

Dyskusja naukowa oprócz sporu o „nazwę przewodnią” koncentruje się też wokół tworzenia nazw na określenie typów organizacji, które nie spełniają którejś z wyżej wymienionych cech i są przez to organizacjami quasi-pozarządowymi. W wyniku tej dyskusji liczba typów podmiotów trzeciego sektora systematycznie rośnie. Dla analizy funkcjonalnej najważniejsze jest jednak uchwycenie różnorodności organizacji ze względu na rodzaj ich działań statutowych oraz funkcji pełnionych w społeczeństwie obywatelskim. Z tej perspektywy warto wyróżnić cztery rodzaje organizacji: (i) organizacje dobroczynne, (ii) organizacje wzajemnościowe, (iii) organizacje rzecznicze oraz (iv) organizacje infrastrukturalne ${ }^{22}$.

Spójrzmy, w jak odmienny sposób poszczególne rodzaje organizacji kanalizują aktywność osób niepełnosprawnych i na rzecz niepełnosprawnych. I tak, organizacje wzajemnościowe są przejawem samoorganizacji samych osób niepełnosprawnych i osób $\mathrm{z}$ ich bezpośredniego otoczenia społecznego, przede wszystkim członków rodzin. Wsparcie świadczone jest tu w trybie „sobie nawzajem” (zarówno na poziomie jednostek, jak i rodzin), ale cennym doświadczeniem jest samo uczestnictwo osób niepełnosprawnych w sieci społecznej, jaką wytwarza członkostwo (dlatego moc inkluzyjną mają przede wszystkim stowarzyszenia) i wspólne działania. Organizacje wzajemnościowe mogą mieć zarówno charakter niskosformalizowany, będąc przejawem samopomocy środowiskowej, jak i wysokosformalizowany, stając się profesjonalnymi świadczeniodawcami

$21 \mathrm{~W}$ nawiasie komentarze własne, związane $\mathrm{z}$ niemożnością dosłownego tłumaczenia terminów angielskich na język polski, bez zniekształcenia kontekstu ujęcia Salamona.

22 Nieco odmienne ujęcie, ale również bazujące na rozróżnieniu kluczowych funkcji w: Zimmer 2004: 15-16. Zob. też analizę funkcji organizacji pozarządowych w: Leś 2013. 
określonych usług społecznych. Takie wzajemnościowe organizacje usługodawcze rozwinięte są zwłaszcza na południu Europy, gdzie silna jest tradycja ekonomii społecznej (por. Geletta, Grewiński 2014). W Polsce w środowisku osób niepełnosprawnych w tej grupie organizacji dominują podmioty samopomocowe.

Organizacje dobroczynne działające na rzecz osób chorych, niepełnosprawnych i innych jednostek i grup słabszych odwołują się do altruizmu i oferują pomoc typu ,jedni drugim", a więc przede wszystkim są formą zaangażowania ludzi zdrowych i sprawnych na rzecz osób niepełnosprawnych. Ale osoby niepełnosprawne poprzez organizacje dobroczynne mogą też angażować się - na przykład jako wolontariusze - $\mathrm{w}$ akcje na rzecz innych osób i środowisk potrzebujących pomocy. Organizacje z tej grupy mogą zarówno prowadzić tradycyjną działalność charytatywną, w dużej mierze o charakterze akcyjnym, jak i prowadzić określone działania sprofesjonalizowane, zwłaszcza w formule placówkowej. W Polsce, na przykład, organizacje pozarządowe prowadzą liczne warsztaty terapii zajęciowej, zakłady aktywności zawodowej, centra integracji społecznej czy środowiskowe domy samopomocy.

Z kolei organizacje rzecznicze osób niepełnosprawnych nie prowadzą bezpośredniej działalności pomocowej ani w trybie „sobie nawzajem”, ale ,jedni drugim”. Istotą ich aktywności rzeczniczej jest bowiem domaganie się odpowiednich działań na rzecz osób niepełnosprawnych ze strony organów państwa, instytucji i służb publicznych, czasem także innych podmiotów, np. biznesu i najszerzej - odpowiedniego traktowania osób niepełnosprawnych w społeczeństwie, w przestrzeni publicznej (por. Wygnańska 2006). Organizacji stricte rzeczniczych działających w Polsce na rzecz osób niepełnosprawnych jest niewiele, jest to bowiem aktywność stosunkowo najbardziej wyspecjalizowana. Działania takie prowadzi w Polsce między innymi Fundacja Integracja. Znacznie więcej organizacji łączy działalność rzeczniczą ze 
wsparciem bezpośrednim i traktuje tę pierwszą jako aktywność uzupełniającą świadczenie usług.

Misją organizacji infrastrukturalnych jest prowadzenie działalności nie na rzecz ludzi w potrzebie, ale na rzecz innych organizacji działalność taką prowadzących. Wyróżniamy dwa podstawowe rodzaje organizacji infrastrukturalnych. Pierwszy to organizacje parasolowe, będące zrzeszeniami, federacjami organizacji członkowskich i prowadzące działalność rzeczniczą; często jest to działalność w interesie organizacji, ale pośrednio również na rzecz beneficjentów organizacji. Organizacje funkcjonujące w środowisku osób niepełnosprawnych i prowadzące działania na rzecz tego środowiska powołały liczne takie infrastrukturalne organizacje parasolowe. Działają one na poziomie ogólnopolskim (np. Polska Federacja Związków Stowarzyszeń Osób Niepełnosprawnych), regionalnym (np. Federacja Mazowia), powstają także „parasole” reprezentujące interesy organizacji „branżowych”, wyprofilowanych na wspieranie osób z określonym rodzajem dysfunkcji, niesprawności (np. Ogólnopolska Federacja Organizacji Osób Niesprawnych Ruchowo). Drugi rodzaj organizacji infrastrukturalnych to centra wsparcia prowadzące szkolenia i inne działania wspierające rozwój kadr trzeciego sektora i inne aspekty profesjonalizacji trzeciego sektora. Tego typu organizacje wspierają np. profesjonalizację sportu dla niepełnosprawnych. Przykładem Związek Stowarzyszeń „Polska Federacja Bocci Niepełnosprawnych” zrzeszający stowarzyszenia, ale także kluby i ośrodki sportowe czy fundacje upowszechniające Bocci - dyscyplinę sportową osób niepełnosprawnych.

Przedstawiona funkcjonalna typologia organizacji pozarządowych opiera się na wyróżnieniu ich funkcji dominującej. W praktyce organizacje zazwyczaj łączą zaangażowanie na różnych polach. Jak już wspomniano, organizacje świadczące pomoc niepełnosprawnym łączą takie bezpośrednie zaangażowanie z rzecznictwem. Przykładem Fundacja Synapsis działająca na rzecz osób z autyzmem. Z kolei 
organizacje wzajemnościowe, aby korzystać ze wsparcia publicznego, zazwyczaj stosują regułę otwartych drzwi, oferując pomoc nie tylko własnym członkom ${ }^{23}$. I tak, w działalność rzeczniczą mogą być zaangażowane same osoby niepełnosprawne, a przykładem może być program self-adwokatury prowadzony w placówkach Stowarzyszenia na rzecz Osób z Niepełnosprawnością Intelektualną czy działalność Polskiego Forum Osób Niepełnosprawnych, do którego mogą należeć zarówno osoby prawne, jak i osoby fizyczne. Innym przykładem jest Federacja Związków Zawodowych Osób Niepełnosprawnych i Pracowników Zakładów Pracy Chronionej. Przykłady można mnożyć.

Ważne, że wszystkie te organizacje pełnią wobec osób niepełnosprawnych funkcje pośredniczące jako tak zwane mediating structures. W odróżnieniu od programów aktywizacji zawodowej, zaangażowanie społeczne ma tu charakter wielowymiarowy, dając możliwość samym niepełnosprawnym społecznego uczestnictwa w różnych formach i na różnych poziomach. Jak podkreślają Peter Berger i John Neuhaus (Berger, Neuhaus 1990), struktury pośredniczące wywołują efekt empowerment - wzmocnienia i upodmiotowienia obywateli. Dlatego o ile aktywizacja zawodowa osób niepełnosprawnych prowadzona może być we wszystkich sektorach, a w Europie usługi tego typu w coraz większym stopniu przechodzą z sektora publicznego na rynek (contracting out), o tyle reintegracja społeczna możliwa jest przede wszystkim w sektorze trzecim, jako infrastrukturze społeczeństwa obywatelskiego. Osoby niepełnosprawne zaangażowane w aktywność społeczną w ramach organizacji pozarządowych są de facto koproducentami usług (własnej i „cudzej”) reintegracji społecznej.

Niestety, w warunkach polskich koprodukcja usług to raczej postulat niż diagnoza sytuacji. Pewien wgląd w sy-

23 Jest to wymóg formalny, w ten sposób działalność staje się działalnością pożytku publicznego. 
tuację w tej materii dało piszącemu te słowa uczestnictwo w latach 2013-2015 w pracach zespołu eksperckiego oceniającego wnioski w Fundacji im. Stefana Batorego w trzech edycjach konkursu grantowego w ramach tzw. mechanizmu norweskiego dla organizacji pozarządowych na prowadzenie działań ukierunkowanych na rozwiązywanie problemu wykluczenia. W konkursie tym można było uzyskać dodatkowe punkty przy ocenie projektów za zadeklarowanie działań angażujących w sposób partycypacyjny osoby wspierane w realizację projektów. Nagminnym było sprowadzanie takiej partycypacji do współdecydowania pozornego - wybierania przez beneficjentów atrakcji, w których chcieliby uczestniczyć, a więc traktowania partycypacji jako zbioru zachowań konsumenckich, a nie przejawu obywatelskiego współdecydowania. Tak się rzecz miała na poziomie deklaracji, praktyka społeczna prawdopodobnie jest jeszcze mniej optymistyczna.

W Polsce zarejestrowanych jest ok. 100 tys. stowarzyszeń i 17 tys. fundacji (dane według rejestrów sądowych za 2014 r.). Spora część z nich to organizacje martwe, które nie prowadzą działalności statutowej i nie ma nawet komu ich rozwiązać ${ }^{24}$. Na podstawie różnych szacunków można przyjąć, że aktywnie działa w Polsce ok. 60-70 tys. stowarzyszeń i fundacji. 8 tys. polskich NGOs ma status organizacji pożytku publicznego (te podmioty działają, bo brak działalności statutowej i corocznego raportowania prowadziłoby do utraty statusu). Marta Gumkowska szacuje na podstawie ogólnopolskich badań Stowarzyszenia Klon/Jawor, że w Polsce aktywnych jest ok. 6 tys. organizacji pozarządowych działających na rzecz osób niepełnosprawnych (Gumkowska 2009: 2725). Stanowi to ok. $10 \%$ wszystkich aktywnych podmiotów trzeciego

24 W Polsce nie ma administracyjnego mechanizmu wyrejestrowywania organizacji martwych.

25 Dane za 2008 r., w późniejszych badaniach tego stowarzyszenia opublikowanych w raporcie z 2012 r. trudno oszacować dane na ten temat ze względu na odmienny sposób określenia pól działalności organizacji - por. Przewłocka, Adamiak, Herbst 2012. 
sektora: mniej więcej taki procent badanych stowarzyszeń i fundacji (dokładnie 9,2\%) zadeklarowało bowiem w $2008 \mathrm{r}$. zaangażowanie $\mathrm{w}$ zakresie udzielania pomocy osobom niepełnosprawnym i chorym (ibidem). Dodajmy, że osoby niepełnosprawne stanowią według szacunków Głównego Urzędu Statystycznego ok. 12,2\% ludności Polski (dane według Narodowego Spisu Powszechnego z 2011 r.).

$\mathrm{Na}$ podstawie danych statystycznych o organizacjach trzeciego sektora trudno określić poziom społecznego zaangażowania samych osób niepełnosprawnych. Badania pozwalają jednak wskazać czynniki różnicujące poziom zaangażowania osób niepełnosprawnych w działalność organizacji pozarządowych. Jerzy Bartkowski zauważa (Bartkowski 2009: 20$)^{26}$, że w środowisku młodych niepełnosprawnych Polaków przynależność do stowarzyszeń deklaruje $42 \%$ osób niewidomych i niedowidzących, 34,2\% niepełnosprawnych z uszkodzonym narządem ruchu, $21,6 \%$ osób chorych psychicznie i już tylko $18,4 \%$ osób cierpiących na choroby narządów wewnętrznych. Interpretacja takiego rozkładu nie jest oczywista, bo rozkład ten jest prawdopodobnie wypadkową różnych czynników. Dla osób niedowidzących, a zwłaszcza niewidomych, przynależność do organizacji środowiskowej $\mathrm{i}$ korzystanie z jej wsparcia jest po prostu niezwykle przydatne $\mathrm{w}$ ich codziennym społecznym funkcjonowaniu. $\mathrm{Z}$ kolei osoby „na wózkach” mają stosunkowo najmniejsze bariery w aktywnym społecznym funkcjonowaniu, co właśnie ułatwia ich społeczne zaangażowanie $\mathrm{w}$ ruchu stowarzyszeniowym. Osoby z uszkodzonymi narządami wewnętrznymi wydają się tu najbardziej społecznie i środowiskowo izolowane, i, zaznaczmy, paradoksalnie to właśnie one stosunkowo najrzadziej postrzegane są jako osoby niepełnosprawne, wymagające specjalnego traktowania.

26 Badania będące podstawą analiz cytowanego autora objęły populację młodych niepełnosprawnych Polaków i nie można ich w sposób automatyczny ekstrapolować na całą populację osób niepełnosprawnych. 
Jerzy Bartkowski (Bartkowski 2009: 21) zaznacza też, że poziom uczestnictwa w ruchu stowarzyszeniowym osób niepełnosprawnych zależy od poziomu wykształcenia (im wyższe tym częstsze uczestnictwo), poziomu niepełnosprawności (im znaczniejsze tym wyższy poziom uczestnictwa). $Z$ jednej więc strony środowiskowemu zaangażowaniu sprzyja rozwój intelektualny, z drugiej - własna niesprawność i konieczność korzystania z pomocy innych. Zauważmy przy tym, że poziom wykształcenia jest odwrotnie skorelowany z poziomem niepełnosprawności: im niepełnosprawność znaczniejsza, tym zdobycie wykształcenia jest trudniejsze. Bierność lub aktywność społeczna nie są więc „przypisane” osobom niepełnosprawnym ze względu na określone ich cechy; są wypadkową wpływu różnych czynników i uwarunkowań, co mocno wskazuje na potrzebę prowadzenia działań aktywizujących.

\section{WNIOSKI KOŃCOWE}

1. Ramy współpracy międzysektorowej stanowią o tym, że racjonalnym rodzajem zaangażowania organizacji pozarządowych na rzecz osób niepełnosprawnych jest podejmowanie się przez nie prowadzenia określonych placówek wsparcia kosztem aktywności środowiskowej. Prowadzenie placówki zapewnia bowiem znacznie stabilniejszą sytuację finansową organizacji, w tym możliwość pozyskania finansowanych ze środków publicznych quasi-etatów kalkulacyjnych (przynajmniej w perspektywie kilkuletniej w ramach tak zwanych wieloletnich programów współpracy). Tymczasem organizacje pozarządowe prowadzące działalność otwartą, pozaplacówkową zmuszone są corocznie konkurować o bieżące środki w systemie grantowym, mając problem z zapewnieniem ciągłości swych działań czy utrzymaniem w swych zespołach specjalistów. 
W rezultacie zaangażowanie organizacji trzeciego sektora w prowadzenie placówek wsparcia, z których korzystają osoby niepełnosprawne jest w Polsce znaczne. I tak, „w posiadaniu” NGOs jest ok. 2/3 centrów integracji społecznej: na 92 centra działające w 2012 r. 49 prowadzonych było przez stowarzyszenia, 12 - przez fundacje, a 7 - przez społeczne podmioty wyznaniowe (GUS 2013). Na 68 działających w 2012 r. zakładów aktywności zawodowej 43 prowadzone były przez organizacje pozarządowe: 30 - przez stowarzyszenia, 8 - przez fundacje, 5 - przez społeczne podmioty wyznaniowe (ibidem: 6). Analogiczny wskaźnik w przypadku warsztatów terapii zajęciowej jest jeszcze wyższy - ponad 3/4 $\mathrm{z}$ nich to podmioty pozarządowe: na 675 tych podmiotów ogółem 367 prowadzonych było przez stowarzyszenia, 87 przez społeczne podmioty wyznaniowe, a 66 przez fundacje (ibidem: 9). Poziom „uspołecznienia” schronisk i innych instytucjonalnych form wsparcia dla osób bezdomnych i wychodzących z bezdomności jest jeszcze wyższy i przekracza 90\%. Głównymi beneficjentami wszystkich tych placówek są osoby niepełnosprawne (w przypadku WTZ i ZAZ - wyłącznymi). W 2014 r. z usług WTZ, CIS, ZAZ skorzystało łącznie 38,5 tys. osób, z czego $78 \%$ stanowiły osoby z orzeczoną niepełnosprawnością (GUS 2015).

Siłą organizacji pozarządowych jest dobre rozpoznanie potrzeb społecznych i społeczne zakorzenienie prowadzonych działań. Dlatego doceniając zaangażowanie polskich organizacji w pomoc instytucjonalną na rzecz osób niepełnosprawnych i innych grup społecznie marginalizowanych, należy podkreślić niewykorzystany potencjał trzeciego sektora w zakresie działań środowiskowych. Rozwój aktywności środowiskowej wymaga jednak innego niż obecny systemu finansowania wsparcia dla organizacji pozarządowych ze środków publicznych. Jest to o tyle istotne, że w społecznym modelu niepełnosprawności przywiązuje się wagę do funkcjonowania otoczenia społecznego osób niepełnosprawnych, aby umożliwić im możliwie „normal- 
ne" i pełne uczestnictwo w życiu społecznym. Oznacza to priorytet dla działań środowiskowych względem pomocy instytucjonalnej.

2. Programy wsparcia aktywizującego, z których korzystać mogą osoby niepełnosprawne, nie tworzą w Polsce spójnego systemu. System PFRON, na który składają się warsztaty terapii zajęciowej, zakłady aktywności zawodowej i zakłady pracy chronionej, jest systemem „wsobnym" o niskiej „drożności”, tj. mocno ograniczonych przepływach beneficjentów między placówkami wsparcia różnego typu. Niezależnie od systemu PFRON funkcjonuje system zatrudnienia socjalnego, którego wadą jest $\mathrm{z}$ kolei niejasne umocowanie instytucjonalne pomiędzy pomocą społeczną i rynkiem pracy, a z którego usług mogą korzystać osoby niepełnosprawne uznane przez ustawodawcę za jedną z grup wykluczonych społecznie. Niepełnosprawni są też uwzględnieni w działaniach służb społecznych (powiatowe centra pomocy rodzinie, gminne ośrodki pomocy społecznej) i służb zatrudnienia. Oferta tych ostatnich jest jednak w dużej mierze niedostosowana do potrzeb i ograniczeń osób niepełnosprawnych. Dodajmy, że w ramach systemu PFRON narasta sprzeczność interesów między podmiotami zatrudniającymi niepełnosprawnych na otwartym i na chronionym rynku pracy oraz między podmiotami prowadzącymi rehabilitację zawodową i rehabilitację społeczną.

Wszystko to wskazuje na konieczność skoordynowania działań w duchu ,integracji reintegracji”. Działań takich wyraźnie brakuje, co przyczynia się do znaczącego obniżenia skuteczności i efektywności działań aktywizujących adresowanych do osób niepełnosprawnych.

3. (Re)integracja (rehabilitacja) społeczna i (re)integracja (rehabilitacja) zawodowa osób niepełnosprawnych to nie są działania alternatywne, ale kompatybilne - wzajemnie się warunkują i uzupełniają. Właściwe ich pozycjonowanie wymaga, po pierwsze, odpowiedniej sekwencji czasowej: działania z zakresu integracji społecznej powinny poprzedzać 
działania z zakresu integracji zawodowej, nie odwrotnie (Rymsza, Karwacki 2013). Konieczność ta jest tym bardziej oczywista, im głębsze są deficyty, dysfunkcje, niesprawności i inne ograniczenia osób niepełnosprawnych. Po drugie, to raczej integracja zawodowa powinna być traktowana jako działanie „służebne” wobec integracji społecznej niż na odwrót. Tylko w ten sposób wsparcie usługowe upodmiotawia osoby niepełnosprawne. Celem tego wsparcia z perspektywy empowerment (wzmocnić i upodmiotowić) jest dbanie o „dobrostan” osób niepełnosprawnych, ich możliwie pełne uczestnictwo w życiu społecznym. Aktywność zawodowa jawi się wówczas jako droga do samodzielności ekonomicznej, a więc lepszego funkcjonowania społecznego. Jeżeli natomiast to integracja społeczna jest traktowana jako działalność „usługowa” względem integracji zawodowej (a dzieje się tak wówczas, gdy nabywanie umiejętności społecznych służyć ma podniesieniu wskaźnika „zatrudnialności”), istnieje ryzyko instrumentalizacji usług i uprzedmiotowienia samych osób niepełnosprawnych. Mają one wówczas pracować nie tyle dla poprawienia własnej sytuacji życiowej, ale w imię swoiście rozumianej „produktywizacji”.

Polski system wsparcia osób niepełnosprawnych, uwzględniając wszystkie jego segmenty, charakteryzuje się przesadną orientacją na integrację zawodową i jednocześnie niskim wskaźnikiem skuteczności i efektywności tak wyprofilowanych działań. Oznacza to, że jego mocniejsza orientacja na integrację społeczną powinna zarazem zwiększyć „współczynnik humanistyczny” udzielanego wsparcia, jak i podnieść skuteczność i efektywność. Taka reorientacja systemu zwiększyłaby też wykorzystanie usługodawczego potencjału trzeciego sektora. Jest to więc kierunek zmian ze wszech miar wskazany. 


\section{BIBLIOGRAFIA}

Bartkowski Jerzy (2009), Przynależność do stowarzyszeń a aktywność społeczna i zawodowa młodych osób niepełnosprawnych, „Trzeci Sektor”, nr 16, s. 17-25.

Berger Peter, John Neuhaus (1997), To Empower People: The Role of Mediating Structures in Public Policy, American Enterprise Institute, Washington, D.C.

Centra integracji społecznej, zakłady aktywności zawodowej $i$ warsztaty terapii zajęciowej w 2012 roku, (2013), Główny

Urząd Statystyczny, Warszawa.

Centra integracji społecznej, zakłady aktywności zawodowej $i$ warsztaty terapii zajęciowej w 2014 roku, (2015), Główny Urząd Statystyczny, Warszawa.

Chimiak Galia (2006), How Individuals Make Solidarity Work, Ministerstwo Pracy i Polityki Społecznej, Warszawa.

Ciura Grzegorz (2007), Niepetnosprawni na rynku pracy, [w:] Rynek pracy (praca zbiorowa), Studia BAS, Wydawnictwo Kancelarii Sejmu RP, Warszawa.

Frączkiewicz-Wronka Aldona (2004), Zarządzanie ustugami społecznymi. Studium partnerstw publiczno-społecznych, Difin, Warszawa.

Galasiński Dariusz (2013), Osoby niepetnosprawne czy z niepełnosprawnością. Niepetnosprawność - zagadnienia, problemy, rozwiązania, nr 4, http://www.pfron.org.pl/download/5/477/01-DariuszGalasinski.pdf (dostęp 15.12.2015), s. 3-6.

Gąciarz Barbara (2014), Przemyśleć niepetnosprawność na nowo. Od instytucji państwa opiekuńczego do integracji i aktywizacji społecznej, „Studia Socjologiczne”, nr 2, s. 15-42.

Geletta Karolina, Mirosław Grewiński (2014), Usługi społeczne na rzecz osób niepetnosprawnych - doświadczenia międzynarodowe, Wyższa Szkoła Pedagogiczna im. J. Korczaka w Warszawie, Warszawa.

Giermanowska Ewa (red.) (2007), Młodzi niepetnosprawni - aktywizacja zawodowa i nietypowe formy zatrudnienia, Instytut Spraw Publicznych, Warszawa.

Golinowska Stanisława (2004), Integracja społeczna osób niepetnosprawnych. Ocena działań instytucji, Instytut Pracy i Spraw Socjalnych, Warszawa. 
Grewiński Mirosław (2009), Wielosektorowa polityka społeczna. O przeobrażeniach państwa opiekuńczego, Wydawnictwo Wyższej Szkoły Pedagogicznej TWP w Warszawie, Warszawa.

Gumkowska Marta (2008), Sektor pozarzadowy wobec problemu niepetnosprawności. Wyniki badania z 2008 roku, „Trzeci Sektor", nr 16, s. 26-33.

Kamiński Tadeusz (2012), Caritas i polityka. Podmioty wyznaniowe w systemie pomocy społecznej, Wydawnictwo Uniwersytetu Kardynała Stefana Wyszyńskiego, Warszawa.

Karwacki Arkadiusz, Tomasz Kaźmierczak, Marek Rymsza (2014), Reintegracja. Aktywna polityka społeczna w praktyce, Instytut Spraw Publicznych, Warszawa.

Kaźmierczak Tomasz (2003), Stużby społeczne i przedsiębiorczość społeczna - przemiany ładu instytucjonalnego, [w:] Tomasz Kaźmierczak, Marek Rymsza (red.), W stronę aktywnej polityki społecznej, Instytut Spraw Publicznych, Warszawa, s. $173-187$.

Kolarska-Bobińska Lena (red.) (2000), Cztery reformy. Od koncepcji do realizacji, Instytut Spraw Publicznych, Warszawa.

Leś Ewa (2013), Organizacje non profit w nowej polityce społecznej $w$ Polsce na tle europejskim, Oficyna Wydawnicza Aspra-JR, Warszawa.

Ostrowska Antonina, Joanna Sikorska, Barbara Gąciarz (2001), Osoby niepetnosprawne w Polsce w latach dziewięćdziesiątych, Instytut Spraw Publicznych, Warszawa.

Piątek Krzysztof (2012), Oblicza polityki społecznej. W kierunku autonomizacji polityki socjalnej, Wydawnictwo Naukowe UMK, Toruń.

Przewłocka Jadwiga, Piotr Adamiak, Jan Herbst (2013), Podstawowe fakty o organizacjach pozarzadowych. Raport $z$ badania 2012, Stowarzyszenie Klon/Jawor, Warszawa.

Rymsza Agnieszka (2013), Zagubiona tożsamość. Analiza porównawcza sektora pozarzadowego $w$ Polsce $i$ w Stanach Zjednoczonych, Ministerstwo Pracy i Polityki Społecznej, Warszawa.

Rymsza Marek (2002), Poprawność polityczna a praca socjalna na przykładzie „Encyklopedii pracy socjalnej”, [w:] Krzysztof Frysztacki (red.), Wartości i normy społeczne - wokót uwarunkowań i czynników pracy socjalnej, Uniwersytet Jagielloński, Instytut Socjologii, Kraków, s. 87-95. 
Rymsza Marek (2011), Rehabilitacja zawodowa osób niepełnosprawnych a zatrudnienie socjalne $w$ sektorze gospodarki społecznej: problem dualności systemów wsparcia, [w:] Mirosław Grewiński, Marek Rymsza (red.), Polityka aktywizacji $w$ Polsce. Ustugi reintegracji w sektorze gospodarki społecznej, Wydawnictwo Wyższej Szkoły Pedagogicznej TWP w Warszawie, Warszawa, s. 27-43.

Rymsza Marek (2012a), Pracownicy socjalni i praca socjalna w Polsce, [w:] Marek Rymsza (red.), Pracownicy i praca socjalna w Polsce. Między stużbą społeczną a urzędem, Instytut Spraw Publicznych, Warszawa, s. 11-33.

Rymsza Marek (2012b), Aktywizacja osób niepetnosprawnych w Polsce: cztery systemy, jedna polityka?, [w:] Kazimiera Wódz, Krystyna Faliszek, Arkadiusz Karwacki, Marek Rymsza (red.), Nowe priorytety $i$ tendencje $w$ polityce społecznej - wokół integracji i aktywizacji zawodowej, Wydawnictwo Edukacyjne Akapit, Toruń, s. 27-43.

Rymsza Marek (2013), Aktywizacja w polityce społecznej. W strone rekonstrukcji europejskich welfare states?, Wydawnictwo Instytutu Filozofii i Socjologii PAN, Warszawa.

Rymsza Marek, Ewa Giermanowska (2009), Polityka integracji społecznej $i$ zawodowej osób niepetnosprawnych $w$ Polsce: duże nakłady, małe efekty, „Trzeci Sektor”, nr 16, s. 2-8.

Rymsza Marek, Arkadiusz Karwacki (2013), Standardy jakości usług jako narzędzia zarządzania procesami świadczenia ustug reintegracji (rehabilitacji) społecznej i zawodowej $w$ Centrach Integracji Społecznej, Klubach Integracji Społecznej i Zakładach Aktywności Zawodowej, Instytut Spraw Publicznych, Warszawa.

Salamon Lester (2001), What is the Nonprofit Sector and Why Do We Have It?, [w:] J. Steven Ott (ed.), The Nature of the Nonprofit Sector, Westview Press, Bouldner, s. 163.

Zimmer Annette (2004), Civil Society Organizations in Central and Eastern European Countries: Introduction and Terminology, [w:] Annette Zimmer, Eckhard Priller (ed.), Future of Civil Society, Vs Verlag, Wiesbaden, s. 11-27.

\section{Akty prawne}

Ustawa z dnia 7 kwietnia 1989 roku - Prawo o stowarzyszeniach, Dz.U. z 1989 Nr 20, poz. 104, z późn. zm. 
Ustawa z dnia 9 maja 1991 roku o zatrudnianiu i rehabilitacji zawodowej osób niepełnosprawnych, Dz.U. z $1991 \mathrm{Nr}$ 46, poz. 201, z późn. zm. (uchylona w 1997 r.).

Ustawa z dnia 27 sierpnia 1997 roku o rehabilitacji zawodowej i społecznej oraz zatrudnianiu osób niepełnosprawnych, Dz.U. z 1997 Nr 139, poz. 776, z późn. zm.

Ustawa z dnia 24 kwietnia 2004 roku o działalność pożytku publicznego i o wolontariacie, Dz.U. z 2003 Nr 96, poz. 873, z późn. zm.

Ustawa z dnia 13 czerwca 2003 roku o zatrudnieniu socjalnym, Dz.U. z 2003 Nr 122, poz. 1143, z późn. zm.

Ustawa $\mathrm{z}$ dnia 20 kwietnia 2004 roku o promocji zatrudnienia i instytucjach rynku pracy, Dz.U. z 2004 Nr 99, poz. 1001, z późn. zm. Ustawa z dnia 27 kwietnia 2006 roku o spółdzielniach socjalnych, Dz.U. z 2006 Nr 94, poz. 651, z późn. zm.

\section{DISABLED AS AN ACTIVE CITIZEN - ISSUES OF SOCIAL AND PROFESSIONAL INTEGRATION OF PEOPLE WITH DISABILITIES IN POLAND}

\section{(Summary)}

The paper describes two main approaches to activation services offered to persons with disabilities: social (re)integration (rehabilitation / inclusion) and work integration (vocational rehabilitation). Work integration is characterized as an aim and result mainly of the state policies while social inclusion is characterized first of all as a phenomenon of activities undertaken by associations and foundations from the third sector. Author arguers for the complementary character of relation between social inclusion and work integration programs. Both have to produce an empowerment effect through their services. It is also stressed luck of co-ordiation of activation services offered by different institutions as state fund called PFRON, social integration centers, social welfare agencies and job centers.

Keywords: disabled persons, persons with disabilities, social inclusion, work integration, social rehabilitation, vocational rehabilitation, activation services, non-governmental organizations. 